EJIM

25,6

320

Received 27 February 2021

Revised 7 June 2021

Accepted 21 July 2021

\section{Value capture in open innovation markets: the role of patent rights for innovation appropriation}

\author{
Marcus Holgersson \\ Technology Management and Economics, Chalmers University of Technology, \\ Gothenburg, Sweden, and \\ Ove Granstrand \\ Mathematical Sciences, Chalmers University of Technology, Gothenburg, Sweden
}

\begin{abstract}
Purpose - The role of patents for appropriating (capturing) value from innovation investments has for decades been of major interest to both practitioners and academics in innovation management. Many studies have implicitly assumed that firms appropriate value through in-house creation and marketing of innovative products and services, and that the main function of patents is to protect the exclusive sales in product and service markets. We challenge this assumption in light of the variety of business models, strategies and markets now being available, including different organizational and market forms of open innovation.

Design/methodology/approach - A conceptual framework and typology of open innovation markets is developed, and the role of patents for appropriation is investigated in these markets among 172 Swedish technology-based firms.

Findings - The results show that the importance of patents has a skewed distribution with some firms rating patents very important and with a fat tail of firms rating patents less important. Most importantly, the results indicate that patents are enabling exchange and technology trade in various types of open innovation markets rather than only supporting vertically integrated business models. Thus patents were found to help rather than hinder the use of open innovation markets.

Originality/value - The paper makes two main contributions. First a theoretical reinterpretation of open innovation with a conceptualization of open innovation markets for appropriation of innovation values. Second an empirical illustration of new roles of patents for appropriating innovation values in these markets. The paper in addition illustrates the use of a counterfactual approach to questionnaire surveys, as well as the complementarities between patents and other means of appropriation.
\end{abstract}

Keywords Appropriability, Counterfactual analysis, Intellectual property, Open innovation, Patent, Startup, Value capture

Paper type Research paper

\section{Introduction}

"In the beginning there were markets" (Williamson, 1975, p. 20) is a common premise in theories of the firm in the transaction cost economics framework. According to this view, firms are started in case market transaction costs are too high (Coase, 1937; Williamson, 1975). But one could just as well premise that "in the beginning there were startups", who

(C) Marcus Holgersson and Ove Granstrand. Published by Emerald Publishing Limited. This article is published under the Creative Commons Attribution (CC BY 4.0) licence. Anyone may reproduce, distribute, translate and create derivative works of this article (for both commercial and non-commercial purposes), subject to full attribution to the original publication and authors. The full terms of this licence may be seen at http://creativecommons.org/licences/by/4.0/legalcode

The authors gratefully acknowledge the financial support from the Awapatent Foundation (Awapatent AB:s Stiftelse för Främjande av Immaterialrättslig Vetenskaplig Forskning) and Jan Wallanders och Tom Hedelius stiftelse (Grant P20-0286). The feedback from Sarah van Santen, Raluca Ratiu and participants at the 2016 R\&D Management Conference at University of Cambridge is gratefully acknowledged.
European Journal of Innovation Management Vol. 25 No. 6,2022 pp. $320-339$ Emerald Publishing Limited 1460-1060

DOI 10.1108/EJIM-02-2021-0114 
eventually create and enter various types of markets in which they exchange with other stakeholders. In other words, the creation story could go both ways. However, what comes before both firms and markets are some kind of ownership and control over resources and some kind of contractual agreements in a broad sense. In fact, the genesis of a startup firm is arguably the entrepreneur's ownership and control over some intangible resource in form of a proprietary business idea, possibly protected by secrecy and associated with a trademark (Granstrand, 1998). This view thus renders a key creationary role to intellectual property (IP) for firms. As a firm evolves and matures, more resources are acquired and exploited through various market exchanges and organizational arrangements and the business idea may then evolve as well, being articulated in form of a business model and a business strategy. IP rights (IPRs) enable such market exchanges for intangibles (North, 1981) and thus play a key creationary role also for markets in intangibles.

This central role of markets for innovation processes has been articulated-albeit sometimes implicitly - in the vibrant research literature on open innovation. Open innovation is "a paradigm that assumes that firms can and should use external ideas as well as internal ideas, and internal and external paths to market, as firms look to advance their technology" (Chesbrough, 2003, p. XXIV). For example, this research has shown how external sources of innovation and external commercialization channels complement integrated business models (Granstrand et al., 1992; Cassiman and Veugelers, 2006; Dahlander et al., 2021), and several reviews of open innovation research indicate a tremendous growth and interest in this phenomenon over the last two decades (Elmquist et al., 2009; Dahlander and Gann, 2010; West and Bogers, 2014; Bigliardi et al., 2021). Most of this research has focused on large firmsrather than startups - and how they can benefit from less integrated innovation processes, such as external search and sourcing of ideas (Laursen and Salter, 2006; Van De Vrande et al., 2009b; Jeppesen and Lakhani, 2010; Lopez-Vega et al., 2016), engaging external developer communities (Dahlander and Wallin, 2006; Shaikh and Levina, 2019), acquisition of innovative firms (Granstrand and Sjölander, 1990; Vanhaverbeke et al., 2002), R\&D collaborations (Enkel et al., 2009), licensing (Laursen et al., 2017; Holgersson et al., 2018) and spinning out innovations that are not aligned with the internal business model (Chesbrough and Chen, 2013). More recently scholars have also identified the need to look into open innovation practices among startups and SMEs (Usman and Vanhaverbeke, 2017). Indeed, technology-based startups and small firms are often involved in open innovation through their interaction with multiple stakeholders and engagement in various markets in the innovation process (Van De Vrande et al., 2009a; Spender et al., 2017; Agostini and Nosella, 2019).

A question that arises both in connection to startups (Holgersson, 2013) and open innovation (Alexy et al., 2009) is that of what role patents - a specific form of IP-play. For open innovation, patents were initially questioned due to the assumption that their primary use is to keep technology safely locked up and protected from the use of others (Bogers, 2011). There are indications, however, that patents and other IPRs help to govern and control open innovation processes (Zobel et al., 2016; Holgersson et al., 2018; Zobel and Hagedoorn, 2020). Indeed, open innovation is related to stronger motives to patent than closed innovation (Holgersson and Granstrand, 2017). For startups and small firms the role of patents is still questioned. For example, the size of the patent portfolio does not necessarily improve sales performance among small firms (Agostini et al., 2015), while it does seem to decrease the likelihood of bankruptcy (Kato et al., 2021). Several studies have found that small firms have lower patent propensities than large firms (Arundel and Kabla, 1998; Brouwer and Kleinknecht, 1999; Chirico et al., 2020). An explanation of this difference is that startup firms have limited resources for monitoring and enforcing the patents that they are granted (Holgersson, 2013).

But patents have actually been found to be of relatively limited importance for value capture across firm sizes by a number of research studies following in the footsteps of the
Value capture in open innovation markets

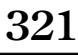


EJIM

25,6

seminal so-called Yale study by Levin et al. (1987). The Yale study was the first one to investigate the effectiveness of patent rights for appropriation relative to other means (such as secrecy, sales or service efforts, lead time, and learning). In general, appropriation studies have been designed to investigate the effectiveness of various means either for protecting the competitive advantages of new or improved products and processes (e.g. Levin et al., 1987; Harabi, 1995) or for protecting innovations against imitations (e.g. Brouwer and Kleinknecht, 1999; Leiponen and Byma, 2009). By and large the conventional wisdom emanating from these studies points out a secondary, if not minor, role for patent rights as compared to other means for appropriation.

However, these appropriation studies have typically assumed an integrated firm with inhouse R\&D, production, marketing and sales in product or service markets. We know that firms make use of a variety of business models when creating and capturing value from their innovation assets, and this has been extensively discussed both in the literature on open innovation (e.g. Chesbrough, 2003; Vanhaverbeke et al., 2008; Dahlander and Gann, 2010) and in the literature on business models (e.g. Chesbrough and Rosenbloom, 2002; Björkdahl, 2009; Osterwalder and Pigneur, 2010; Teece, 2010; Bucherer et al., 2012). An important consequence, central to our argument here, is that it is not only product markets that are of importance for enabling value capture but also other types of markets such as technology markets (Arora et al., 2001; Tietze, 2012), capital markets (Conti et al., 2013; Nylund et al., 2019) and markets for corporate control (Granstrand and Holgersson, 2013; Arora et al., 2021). For example, a technology-based startup may successfully commercialize and capture value from its innovation by patent sales, licensing or being acquired by a large established firm that continues to develop and commercialize the startup's innovations.

While Chesbrough (2003) treated these as "external paths to market" in his definition of open innovation - contrasting them with the internal path to product and service marketswe here prefer to see them as different types of markets. Each one relates to a specific type of exchange between the firm and external actors or stakeholders. By using the concept of open innovation markets we want to highlight the fact that open innovation involves exchange in different non-product and non-service markets (Granstrand, 2018, 2020). Every exchange in such markets holds the potential to create and appropriate value (Gans and Ryall, 2017; Stoelhorst, Forthcoming). While this market perspective of open innovation leads our thinking toward exchange, it also leads our thinking toward the different actors that the markets connect, such as communities, partners, financiers and customers, in line with stakeholder theory (Freeman, 2015; Stoelhorst, Forthcoming) and innovation ecosystem conceptualizations (Adner, 2006; Granstrand and Holgersson, 2020). When adopting this broader perspective of relevant markets for value capture-and indeed also for value creation - the question of the role of patents for appropriation needs to be revisited. Therefore, the purpose of this paper is threefold; to further develop the concept of open innovation markets, to illustrate them empirically, and to explore the role of patent rights for creating and capturing innovation value in such markets.

We address this purpose by conceptualizing open innovation markets, leading to a framework with four distinct markets in which value from innovation is created and captured. Then we continue to explore the role of patents with empirical data from 172 technology-based firms of different sizes, and in so doing especially focus on the role of patents for startups.

\section{Conceptual framework}

\subsection{Toward open innovation markets}

As remarked above the traditional typology of appropriation strategies emanating from the Yale study are primarily premised on a strategy for closed innovation, i.e. a strategy for product 
commercialization via integrated in-house $\mathrm{R} \& \mathrm{D}$, production and marketing. In order to frame appropriation strategies also in the context of open innovation, a typology of inbound and outbound technological innovation strategies is used as a point of departure, see Figure 1. This typology of technology strategies emanates from Granstrand (1982, p. 66), which to our knowledge was the first comprehensive study of quasi-integrated forms of innovation organization in Europe - what is today commonly called open innovation (Chesbrough, 2003). The typologies on the inbound and outbound side, respectively, have corresponding strategy types, including: in-house R\&D and in-house production and marketing; acquisitions and spinoffs; different types of collaborations, joint ventures and external partnering; in- and outlicensing and divestment; and finally residual types of in- and outflows of technical information and knowledge (i.e. technology). Each type of innovation strategy corresponds to particular types of transactional contractual arrangements used in different markets for labor, products/ services, company equity, collaborations, licenses, patents and information (e.g. Granstrand et al., 1992; Granstrand, 1999). Each type of contractual arrangement (employment contract, collaboration contract, licensing contract, etc.) thus corresponds to a particular type of innovation market for closed and open innovation with varying degrees of organizational integration depending on the nature of the contractual obligations. The demand sides of these innovation markets are constituted by the use of technology acquisition (=sourcing) strategies for inbound innovation and the supply sides are constituted by the technology exploitation (=commercialization) strategies for outbound innovation. Needless to say neither strategies nor markets are excluding each other as a rule but strategy mixes and market mixes are not only feasible but typical.

The phenomenon of open innovation could thus be viewed from a firm's perspective as a set of strategies, being the traditional perspective on open innovation. But it could just as well be viewed from a reverse perspective as a set of open innovation markets. The innovation strategy perspective and the innovation market perspective enrich each other and we will make a plea for using a dual perspective in analyzing open innovation. Each pair of technology acquisition and exploitation strategies moreover constitutes a type of business model for input and output markets, combining modes for both value creation and value capture (Chesbrough and Rosenbloom, 2002; Björkdahl, 2009; Teece, 2010).

\section{Technology Acquisition Strategies for \\ Inbound Innovation}

\section{Technology Exploitation \\ Strategies for
Outbound Innovation \\ Strategies for
Outbound Innovation}

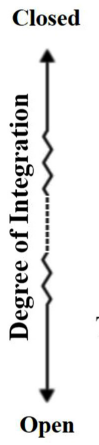

Internal R\&D

\section{Acquisition of} innovative projects or firms

Joint technology ventures

Technology purchasing

Technology scanning

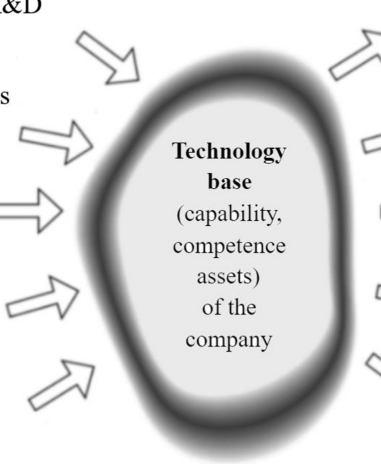

Innovation Market Demand
Value capture in open innovation markets

323
Figure 1.

Typology of

Dissemination and spill-overs

Innovation Market Supply

technology acquisition and commercialization strategies

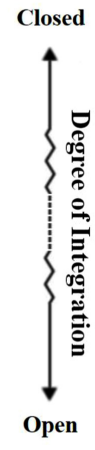


EJIM

25,6

324

What interests us most in this paper are the technology exploitation strategies, since these are capturing value from innovation. Additionally different financing strategies can be used for monetizing from innovation with different financial instruments, including equity and debt-based instruments. By switching from a strategy to a market perspective in line with the argument above, the appropriation strategies can be conceptualized as exchange in four distinct markets, see Figure 2. First, there are markets for technology-based products and services. This is what we call a closed innovation market, in contrast to the following three open innovation markets. Second, there are markets for collaboration, in which partners are matched to collaborate on the development, production and the eventual sales of technologybased products and services. Third, there are markets for technology itself. Firms make use of for example licenses and patent sales to capture value in these markets. Fourth, there are markets for financing and corporate control. Firms make use of these markets by selling equity, bonds and other financial instruments related to the technology. These four markets relate to contractual obligations including different types of assets in which innovation value is realized and exchanged, and thereby monetized by the focal firm and its transactional counterparts [1].

The framework highlights the connection and overlap between appropriation and technology commercialization strategies, business models and financing strategies. From a managerial point of view, such a conceptualization aiming for completeness and distinctiveness is useful since it highlights a set of possible strategic options. For the purpose of this paper, this is especially important since we aim to investigate the role of

Figure 2.

Typology of open innovation markets

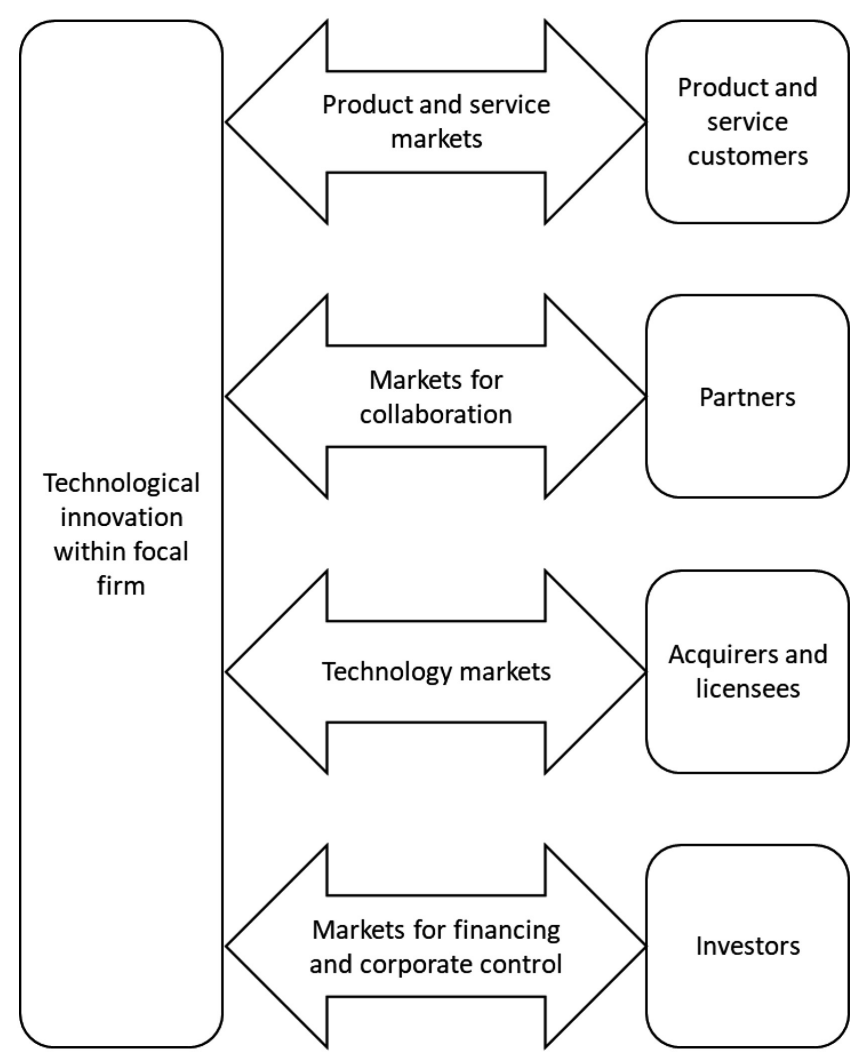


patents for appropriation in different markets. For example, exit is a common appropriation strategy and business model for entrepreneurial ventures (Arora et al., 2021), while it is also an extreme form of equity sales, which in turn is a financing strategy. Similarly, a licensing strategy may be used for appropriating from previous innovation investments (e.g. Arora et al., 2013), but licensing a subset of technologies and/or in a subset of markets may also be a way to finance the buildup of the core business of the company (Chesbrough and Chen, 2013).

\subsection{The role of patent rights for open innovation markets}

The open innovation markets in our framework can be used to capture value from the underlying technological innovation. Moreover, all of these markets can be enabled by intellectual property rights such as patents (e.g. Bader, 2006; Hagedoorn and Zobel, 2015; Zobel et al., 2016; Holgersson and Granstrand, 2017).

Regarding the role of patents for product and service markets, the extant appropriation literature has much to tell us. The typology of means or strategies for appropriation (= value capture) deriving from the seminal Yale study (Levin et al., 1987) has been replicated and somewhat developed in various countries in the 1990s onwards (e.g. Harabi, 1995; Brouwer and Kleinknecht, 1999; Cohen et al., 2000; Arundel, 2001; Leiponen and Byma, 2009). The typology of appropriation strategies used in the Yale study became more or less a de facto standard and dominant design for research on strategies for appropriation, using the strategy types patents, secrecy, market lead time, superior production (moving down the learning curve) and superior marketing. Subsequent studies then expanded the typology of strategies in a number of ways, for example by introducing switching costs and complementary assets along with complementary products. In general, the empirical results from these studies indicate that patents are less important than most other appropriation means (Levin et al., 1987; Harabi, 1995; Kitching and Blackburn, 1998; Brouwer and Kleinknecht, 1999; Cohen et al., 2000; Leiponen and Byma, 2009). However, interdependencies across different means of appropriation were not accounted for in these studies. For example, both patents and secrecy may be used to increase market lead time, which in turn increase relative cost advantages through learning by producing and usage. Thus, the direct role of patents, as measured in these empirical studies, may be secondary and minor, while the indirect role might be important through its impact on other means in such a causal chain, but largely invisible in the data. In other words - using a sports metaphorpatents may play a role of assisting in scoring.

Moreover, when expanding the appropriation strategies by including various open innovation markets, there is less research on how technology-based firms and their leaders perceive the role of patents for appropriation. Nevertheless, there are studies indicating that patents may be enablers of these markets. For example, patents enable technology-intensive interorganizational relationships (Zobel et al., 2016). They also help to structure and control technology trade and licensing (Arora et al., 2001; Granstrand, 2000; De Rassenfosse et al., 2016; Holgersson et al., 2018). Finally, when startups reach out to investors for financial capital, there is evidence that patents give them more and faster venture capital in exchange of a stake in the firm itself (Mann and Sager, 2007; Conti et al., 2013; Haeussler et al., 2014). One explanation in previous research is that patents and the information from the patenting process can mitigate information asymmetries between founders and investors (Haeussler et al., 2014). In venture debt financing, patents can be used as collateral (De Rassenfosse and Fischer, 2016). Research shows that patents that can be redeployed by the creditor in case of venture failure are especially useful as collateral in debt financing (Fischer and Ringler, 2014; Hochberg et al., 2018). Finally, research has shown that patents impact pricing in initial public offerings (Heeley et al., 2007).

It is worth noting that the use of different markets for appropriation varies not only across firms, industries and countries, but also over time and across stages in the innovation process

Value capture in open innovation markets 
EJIM

25,6

326

and across markets. A startup, for example, may first use internal entrepreneurial capital, then go for external debt and grant financing, followed by rounds of VC capital and later IPOs, and finally, after a product market launch, capitalization through product or service sales is possible, leading to firm growth. Thus, the applicability of the standard Yale typology and its variants on technology-based startups could be questioned. A large firm has typically acquired substantial complementary assets, experience and financial stability while a startup often is more risk dependent on its input as well as output markets in acquiring and exploiting its smaller resources (Van De Vrande et al., 2009a; Agostini and Nosella, 2019). As to technological resources and innovations a startup could be expected to be less integrated and more dependent upon open innovation than large firms on average. The role of patents may also then be different for startups than for larger firms.

\section{Method}

The empirical data was collected through surveys directed to three different subsamples, with completed questionnaires from 172 technology-based firms, corresponding to an average response rate of $50 \%$. Our sampling focused explicitly on technology-based firms (but not necessarily firms with patents). The data was collected in two rounds between 2011 and 2016 with two different questionnaires, and the results from the first round informed the second round of data collection.

In the first round data was collected from two subsamples of the largest R\&D spenders in Sweden. The first subsample includes the 100 largest R\&D spenders among Swedish large firms. In this subsample 57 firms responded (57\%). The second subsample includes the 100 largest R\&D spenders among Swedish SMEs. Given that we focused on the firms with the largest $R \& D$ spending these firms tended to be in the larger end of the SME spectrum. In this subsample 34 firms responded (34\%). These two subsamples received the first questionnaire, and the data was collected during late 2011 and early 2012. The analysis of part of this dataset showed that open innovation is related to stronger motives to patent (Holgersson and Granstrand, 2017). The results also showed that motives to patent related to open innovation markets - such as enabling licensing and attracting financing-were significantly more important for smaller firms than for large firms. These results led us to reconsider extant literature on the role of patents for value appropriation among startups, and motivated a third round of data collection.

In the third round data was collected from a sample of 144 of the most promising technology-based startups in Sweden. In light of the finding that the openness of innovation is related to the strength of patent motives - and due to the fact that small firms tend to be involved in various interorganizational relationships to complement their scarce resources - the startup context is especially useful when exploring the role of patents in open innovation markets. Relevant startups were identified through an article series in the leading Swedish technology newspaper NyTeknik over several years. In this subsample 81 firms responded (56\%) [2]. This subsample received the second questionnaire, and the data was collected during late 2015 and early 2016.

The focus for the sampling was to collect data from the most relevant firms, and having the most relevant person filling in the questionnaire. The questionnaires to large firms and SMEs were sent to the CTO, head of R\&D, head of R\&D business unit or similar position and were to a very large extent also answered by these people. The questionnaires to startups were sent to the CEO and were also to a very large extent answered by these people. We believe that these have been the most suitable persons within the firms to answer the questions, and that this has contributed to increased reliability of the data (avoiding the patent bias of IP managers, for example). Furthermore, focusing on firms active in developing new technologies increases the relevance of the results, as compared to 
studies focused more broadly on for example manufacturing firms in general (cf. Kitching and Blackburn, 1998; Cohen et al., 2000). For a description and summary of the three samples, see Table 1.

The survey used in the second round was different from the one used in the first round. For example, the second survey was designed to better capture the role of patents in open innovation markets, and it used 7-point rather than 5-point Likert scales. The second survey, due to its focus on open innovation markets, also asked about means for protecting the competitive advantage of new or improved technologies, rather than means for protecting the competitive advantage of new of improved products and services. This change indicates our ambition to better capture the fact that technologies of startups - or any other firms - are not necessarily commercialized by being productified and/or servitized. Moreover, we utilized a counterfactual method in the second round to complement the factual data. This gave a richer understanding of the role of patents for startups' engagement in open innovation markets and how patents interact with other means for appropriation. We collected data on the role of patents in various strategies and markets for appropriation and how a total reduction of patenting as a counterfactual would impact these. We further analyzed the relationships between various factual strategy choices and how the (counterfactual) role (a total reduction of) patenting influenced these strategy choices. Counterfactual analysis is prevalent in various managerial, economic and legal practices, for example in investment appraisals, damage calculations and patent examination [3]. Counterfactual analysis has long been used in economic studies (e.g. Mansfield, 1988; Kim et al., 2008). More recently counterfactual analysis has also been called for in strategy research (Burgelman et al., 2018).

Counterfactual analysis in strategy studies could theoretically be seen as a causal analysis of what strategies would have been deployed if a chance or a decision node had been removed in a decision tree as it evolves over time. If a strategic option is removed at some stage, say the real option of taking out a patent, and another strategy then had been optimal, the difference between factual and counterfactual outcomes would be an indicator of the strategic value or importance of the option. Empirically, however, it is difficult to distinguish whether respondents' answers reflect hypothetical forecasts or counterfactual backcasts. The indicator value might nevertheless be reasonably robust. The situation becomes more complex in case of different mixes of strategy options being present or absent in the mix, such as mixes of technology strategies and mixes of appropriation strategies.

Suppose there are $n$ options labeled $1, \ldots, n$ with a value function $V$ defined on every subset of the options with values $V(S)$, where $S$ is a subset of $[n]$ [4]. If one option $j$ (such as patenting) is removed, the value of the remaining strategy mix becomes $V(S y)$ and the marginal value added to the strategy mix $S j$ by option $j$ (patenting) is equal to $V(S)-V(S)$ ). A pure strategy with only patenting then has a stand-alone value $V(j)$, which is however typically not equal to $V(S)-V(S y)$ due to complementary and/or substitute relationships between strategy options. This is exactly why the counterfactual approach has the potential
Value capture in open innovation markets

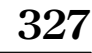

\begin{tabular}{|c|c|c|c|c|c|c|c|c|}
\hline $\begin{array}{l}\text { Round of } \\
\text { data } \\
\text { collection }\end{array}$ & Sample & Respondents & $\begin{array}{l}\text { Number of } \\
\text { responding } \\
\text { firms }\end{array}$ & $\begin{array}{c}\text { Chemistry, } \\
\text { biotechnology, } \\
\text { pharmaceuticals }\end{array}$ & $\begin{array}{l}\text { Electronics, } \\
\text { IT, power }\end{array}$ & Mechanical & $\begin{array}{c}\text { Other } \\
\text { industries }\end{array}$ & \\
\hline First & $\begin{array}{l}\text { Large } \\
\text { firms }\end{array}$ & $\begin{array}{l}\text { CTOs or } \\
\text { equivalent }\end{array}$ & 57 & $19 \%$ & $32 \%$ & $28 \%$ & $21 \%$ & \\
\hline First & SMEs & $\begin{array}{l}\text { CTOs or } \\
\text { equivalent }\end{array}$ & 34 & $35 \%$ & $41 \%$ & $18 \%$ & $6 \%$ & Table 1 \\
\hline Second & Startups & CEOs & 81 & $21 \%$ & $51 \%$ & $11 \%$ & $17 \%$ & Sample descriptions \\
\hline
\end{tabular}


EJIM 25,6

\section{8}

Table 2.

Average importance of various means of protecting the competitive advantage of new or improved products and processes in large firms and SMEs (scale: $1=$ not at all important; 5 = very important) to provide valuable insights, which would not be obtainable from the purely factual approaches that have been used in appropriation studies to date. A potential weakness of the counterfactual approach is that the analysis is based on perceptions among the respondents. However, this is not necessarily a bad thing. Perceptions among managers guide their decisions and data on their perceptions thus tell us much about their decision-making, making it an important complement to, for example, regression analysis.

A final note regarding the method is that the data analysis is exploratory rather than hypothesis-testing. Thus, rather than deductively formulating and testing hypotheses, we analyze the data to explore properties and relationships to further extend our understanding of appropriation in a broad set of open innovation markets, and the role of patents in that.

\section{Empirical results}

Our empirical results initially confirm previous studies' results, with a relatively limited importance of patents for protecting the competitive advantage as compared to other classical means for appropriation, such as secrecy, complexity, creation of market lead time by other means, cost reductions in production and marketing and after-sales service. This goes for all three of our subsamples, see Tables 2 and 3, although one should note the slight variation in questions, where Table 2 is about the competitive advantage of new of improved products and services among large firms and SMEs, while Table 3 is about the competitive advantage of new or improved technologies that are not necessarily productified and/or servitized among startups. Also note the differences in scales, here presented in the table captions. While indicating a relatively limited importance of patents as compared to a number of other means of appropriation, Table 2 also shows that patents, at least product patents, are more important than some means, such as complementary sales and complementary manufacturing, and switching costs.

How important are the following means of

$$
\text { Products }
$$

Processes protecting the competitive advantages of new or improved products and processes on average for your company?

\begin{tabular}{|c|c|c|c|c|}
\hline $\begin{array}{l}\text { or improved products and processes on } \\
\text { average for your company? }\end{array}$ & $\begin{array}{l}\text { Large firms } \\
\text { (std. dev.) }\end{array}$ & $\begin{array}{l}\text { SMEs (std. } \\
\text { dev.) }\end{array}$ & $\begin{array}{l}\text { Large firms } \\
\text { (std. dev.) }\end{array}$ & $\begin{array}{l}\text { SMEs (std. } \\
\text { dev.) }\end{array}$ \\
\hline (a) Patents & $3.57(1.38)$ & $3.29(1.20)$ & $2.52(1.41)$ & $2.67(1.40)$ \\
\hline (b) Secrecy & $3.74(0.99)$ & $4.07(0.96)$ & $3.58(1.30)$ & $3.68(1.22)$ \\
\hline (c) Complexity of product or process design & $3.70(0.96)$ & $3.72(1.05)$ & $3.49(1.24)$ & $3.38(1.00)$ \\
\hline (d) Keeping qualified personnel in the firm & $4.38(0.62)$ & $4.42(0.91)$ & $4.16(0.86)$ & $4.23(0.84)$ \\
\hline $\begin{array}{l}\text { (e) Creation of lead times by other means than } \\
\text { (a) - (d) }\end{array}$ & $3.73(0.88)$ & $3.63(0.83)$ & $3.19(1.06)$ & $3.35(1.01)$ \\
\hline (f) Cost reductions in production & $3.88(1.06)$ & $3.58(1.16)$ & $4.02(0.90)$ & $3.64(1.14)$ \\
\hline (g) Complementary sales & $3.17(0.99)$ & $3.10(0.92)$ & $2.82(1.09)$ & $2.68(1.29)$ \\
\hline (h) Complementary manufacturing & $2.50(0.94)$ & $2.48(0.76)$ & $2.54(1.08)$ & $2.33(0.94)$ \\
\hline (i) Marketing and after-sales service & $3.64(0.86)$ & $3.74(1.14)$ & $3.06(1.15)$ & $2.96(1.32)$ \\
\hline $\begin{array}{l}\text { (j) Creation of costs for customers to switch } \\
\text { supplier }\end{array}$ & 3.13 (1.03) & $2.88(1.36)$ & $2.88(0.95)$ & $2.56(1.46)$ \\
\hline $\begin{array}{l}\text { (k) Securing formal contractual control over } \\
\text { important actors in the value chain (key } \\
\text { suppliers and customers) by contracting } \\
\text { or integration (e.g. through M\&As) }\end{array}$ & 3.14 (1.04) & 3.34 (1.12) & $3.11(1.10)$ & 2.92 (1.13) \\
\hline $\begin{array}{l}\text { (1) Securing informal control over important } \\
\text { actors in the value chain (e.g. through trust } \\
\text { and personal relations) }\end{array}$ & 3.40 (1.02) & $3.72(1.05)$ & 3.12 (1.03) & 3.50 (1.04) \\
\hline
\end{tabular}


In addition to indicating the factual importance of various means for improving appropriation, Table 3 also presents data on the counterfactual changes of other means if patenting would not have been used at all by the studied firms. All other means would increase in importance, and the increases are significant. Thus, despite patents being of less importance than some other means for appropriation, not using patents would nevertheless have a significant impact on the use of other means according to CEOs of startups.

An additional observation from Tables 2 and 3 is that the standard deviation of the importance of patents is relatively high as compared to the standard deviations of the importance of other means. Thus, there is a larger variation of importance of patents across firms, as compared to the other means, warranting further analysis. Therefore, histograms of the importance for the three different samples are presented in Figures 3-5, and these histograms indicate a skewed importance of patents among startups and large firms, with many firms stating that patents are very important, but with a fat tail of firms stating that patents are less important. Many other mechanisms are also skewed, but with fewer firms finding them of very low importance. Thus, while the importance of patents on average is relatively low, there is still a large number of firms finding patents very important for protecting the competitive advantage of new or improved products, process and technologies.

The skewness among large firms and startups could lead us to believe that different firms focus on different appropriation mechanisms, so that some firms focus very much on patenting, for example, instead of other appropriation mechanisms such as secrecy. However, there are significant positive correlations between a number of different mechanisms (see Table 4), not the least between patents and secrecy, pointing at a complementary relationship.

How important are the following means of protecting the competitive advantage of new or improved technologies for your company?

Patents

Secrecy (including trade secrets)

Creation of market lead times by other means than patents and secrecy

Keeping qualified personnel in the firm Cost reductions in the production of new or improved products and services Marketing and after sales service (including branding and trademarks)
Value capture in open innovation markets

329

Table 3.

Average importance (scale: $1=$ not at all important; 7 = very important) and counterfactual change in importance (scale: $-3=$ large decrease in importance; $0=$ no change; $+3=$ large increase in importance) of various means of protecting the competitive advantage of new or improved technologies among startups

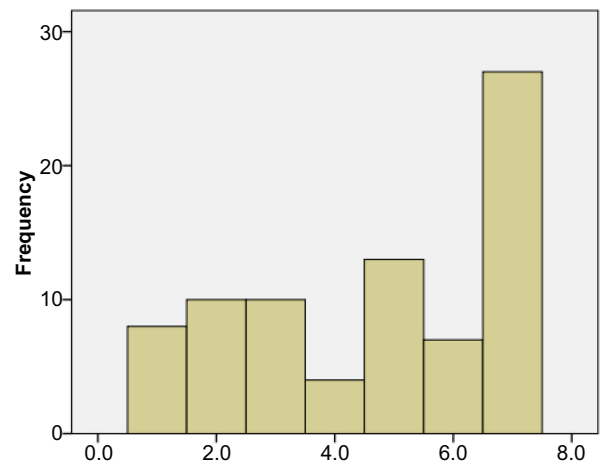

Figure 3.

Histogram of the importance of patents for protecting the competitive advantage of new or improved technologies among technology-based startups (scale: $1=$ not at all important;

$7=$ very important) 
EJIM

25,6

\section{0}

The counterfactuals in Table 3 further illuminates these relationships, indicating that decreasing the use of patents to zero would significantly increase the importance of the other appropriation mechanisms. It is here important to remember the difference between the counterfactuals, indicating that decreasing patenting would lead to increasing secrecy within the same firm, and the correlations, indicating that firms placing high importance on patenting also place high importance on secrecy, for example. Needless to say, correlations like these do not indicate causality but possibly complementarity, while counterfactuals like these may indicate causality but not necessarily complementarity (or substitutability).

Hitherto we have looked at appropriation in general, but not at how patents enable appropriation in different open innovation markets. Following our conceptual framework in chapter 2, Table 5 first presents the importance of various technology exploitation strategies among startups - corresponding to transactions in the open innovation markets in our framework. An integrated strategy of in-house development, production, and sales in product and service markets is most important, followed by partnerships and collaborations, sales of technologies and finally selling the firm (exit).

Figure 4 .

Histogram of the importance of patents for protecting the competitive advantage of new or improved products among R\&Dintensive large firms (scale: $1=$ not at all important; 5 = very important)
Figure 5.

Histogram of the importance of patents for protecting the competitive advantage of new or improved products among $R \& D$ intensive SMEs (scale: $1=$ not at all important; $5=$ very important)
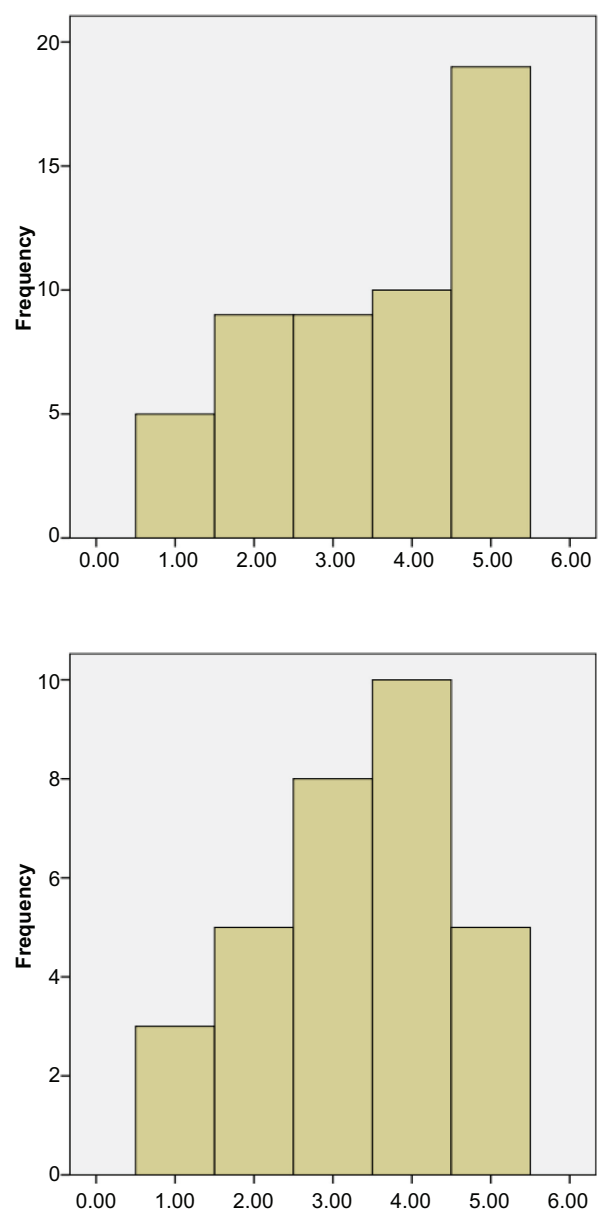


\section{Pearson}

correlation

Sig. (2-tailed)

Pearson

(b) Secrecy (including trade secrets)

(c) Creation of market lead times by other means than patents and secrecy

(d) Keeping qualified personnel in the firm

(e) Cost reductions in the production of new or improved products and services

(f) Marketing and after-sales service (including branding and trademarks)
Sig. (2-tailed)

Pearson

correlation

Sig. (2-tailed)

Pearson

correlation

Sig. (2-tailed)

Pearson

correlation

Sig. (2-tailed)

Pearson

correlation

Sig. (2-tailed) (a)

(b)

(c)

(d)

(e)

(e) (f)

$0.309^{* *}$

0.006

$-0.012$

0.915

0.030

0.791

0.150

0.187

$-0.077$

0.503
0.211

0.061

$$
0.318^{* *} \quad 0.046
$$

$0.004 \quad 0.690$

$\begin{array}{lll}0.373^{* *} & 0.134 & 0.058\end{array}$

$\begin{array}{lll}0.001 & 0.240 & 0.612\end{array}$

$\begin{array}{lll}-0.008 & 0.187 & 0.211\end{array}$

0.185

$\begin{array}{llll}0.944 & 0.099 & 0.063 & 0.104\end{array}$
Value capture in open innovation markets

331

Note(s): **Correlation is significant at the 0.01 level (2-tailed)

How important are the following strategies for commercializing (exploiting) new or improved technologies for your company?

In-house development, production, and sales of technology-based products and services Partnerships and collaborations with other organizations for development, production, and sales of technology-based products and services

Sales of technologies (including licensing) Selling the firm and its technologies to another owner (exit)
Factual

\begin{tabular}{ccc}
$\begin{array}{c}\text { importance (std. } \\
\text { dev.) }\end{array}$ & $\begin{array}{c}\text { Counterfactual } \\
\text { change }\end{array}$ & $\begin{array}{c}\text { Significance } \\
\text { (difference from 0) }\end{array}$ \\
\hline
\end{tabular}

$6.19(1.21)$

0.615

0.001

$5.34(1.48)$

0.554

0.002

$4.97(1.85)$

$4.30(1.91)$

$-0.046$

0.092

0.811

0.626
Table 5.

Average importance (scale: $1=$ not at all important; 7 = very important) and counterfactual change in importance (scale: $-3=$ large decrease in

importance; $0=$ no change $+3=$ large increase in importance) of various strategies for commercializing (exploiting) new or improved technologies among startups

Table 5 also presents the counterfactual changes in importance of the different strategies resulting from a counterfactually assumed total decrease of patenting. The results indicate that the importance of more integrated forms of capitalizing on innovation through the development, production and sales of technology-based products and services, either fully inhouse or in collaboration with others, would then increase.

The importance of technology sales could in turn be expected to decrease, given that patents are sometimes viewed as a contractual basis for enabling technology trade (Hagedoorn and Zobel, 2015; Holgersson and Granstrand, 2017; Merges, 2011; De Rassenfosse et al., 2016). On the one hand, there is no significant support of this in the sample of startups as seen in Table 5. On the other hand, in the samples of R\&D-intensive large firms and SMEs there is a significant agreement to statements that say that patenting new technologies typically increases possibilities both for technology transfer/trade and for doing collaborative and joint R\&D work with other organizations, see Table 6.

Our conceptual framework also adds the strategy to use capital markets through sales of various forms of financial instruments, including both debt and equity capital. Table 7 
EJIM

25,6

\section{2}

presents results on the counterfactual changes, showing that decreasing patenting to a zero would significantly decrease the startups' ability to attract debt capital, and even more so the ability to attract equity capital.

In addition to that, all other counterfactuals in Table 7 are also negative, especially for the market value of the company. However, the ability to attract equity capital stands out as the item being related to the largest counterfactual change if the startups would not use patenting at all.

\section{Discussion}

Our findings related to the classical appropriation question indicates a relatively limited importance of patents for protecting the competitive advantage as compared to other classical means for capturing innovation value, such as secrecy, complexity, creation of market lead time by other means, cost reductions in production and marketing and after-sales service. This goes in line with previous research (e.g. Harabi, 1995; Brouwer and Kleinknecht, 1999; Cohen et al., 2000; Arundel, 2001). However, when investigating the distribution of importance attributed to patents, it turns out that this distribution is skewed with a large number of firms finding patents of large importance for appropriation and a fat tail of firms attributing less importance to patents, at least among large firms and startups.

Patent-related measures, just as other innovation-related measures, have in previous research been found to be skewed as a rule. Most patents are not commercialized, very few are valuable and very very few are very very valuable (Harhoff et al., 2003). This resonates with the fact that most ideas are not used, most R\&D is done by a few firms, radical innovations are rare, etc. This skewness skews research results and results in skewed (distorted) views, apparently paradoxical at times. One example of what has been viewed as paradoxical patenting behavior is that firms do patent frequently even though most patents are of limited use (cf. Mansfield, 1986; Hall and Ziedonis, 2001).

However, this apparently contradictory and unjustifiable patent propensity of firms can be rationalized by viewing patents ex ante as lottery tickets or as insurance premiums, thereby resolving what's referred to as the patenting paradox, i.e. that companies take out a

Agreement to statements about patenting and technology trade and collaboration (scale: $-2=$ completely disagree; $0=$ neither disagree, nor agree; $+2=$ completely agree)

\begin{tabular}{llc}
\hline $\begin{array}{l}\text { To what extent do you disagree or agree with the statement that } \\
\text { patenting new technologies typically increases possibilities for... }\end{array}$ & Mean & $\begin{array}{c}\text { Significance (difference } \\
\text { from 0) }\end{array}$ \\
\hline $\begin{array}{l}\text {..technology transfer and technology trade } \\
\text {..doing collaborative and joint R\&D work with other firms and/or } \\
\text { organizations }\end{array}$ & 0.531 & 0.000 \\
& & 0.000 \\
\hline
\end{tabular}

Table 7.

Counterfactual change (scale: $-3=$ large decrease; $0=$ no change; $+3=$ large increase) of various items among startups
Assume that your company would not have used patenting at all, how would the following items change compared to your current situation?

$\begin{array}{cc}\begin{array}{c}\text { Counterfactual } \\ \text { change }\end{array} & \begin{array}{r}\text { Significan } \\ \text { (difference fr }\end{array} \\ -0.200 & 0.248 \\ -0.277 & 0.057 \\ -0.477 & 0.002 \\ -0.815 & 0.000 \\ -1.79 & 0.000 \\ -1.52 & 0.000\end{array}$


lot of patents without using them (Granstrand, 2018). The expected utility of patents ex ante is then positive, albeit small perhaps, while the factual utility ex post is mostly nil. The same could more or less be said about the expected versus factual rate of return on investments in patenting which is consistent with viewing patents as real options (Bloom and Van Reenen, 2002; Schwartz, 2004). Thus, it is rational, or at least not contradictory, to patent just as it is rational to buy insurance even if your house has not yet burned down [5].

The results here give yet another explanation for why firms do patent despite rating other means for appropriation more important. Other means are only more important on average and the distribution of importance attached by firm respondents to patenting as an appropriation strategy is skewed with many firms considering patents as very important. While the distribution of values of individual patents is very skewed with a large number of more or less worthless patents (see above) and a very thin tail of more (and sometimes very) valuable patents, the distribution of importance of patents across individual firms oppositely consists of a fat tail of firms rating patents with a relatively low importance and a large number of firms rating patents very important, at least in two of our samples. Most of the other means for capturing value are also skewed, but with thinner tails leading to higher averages. While patents are related to a number of requirements, partly explaining the fatness of the tail, the other means are more generally applicable. The fact that most firms find it very important to, for example, keep their qualified personnel from quitting does not decrease the absolute importance of patents among the large share of firms that heavily rely on them, despite the relatively limited average importance across all firms.

Moreover, by broadening our focus from product and service markets to various open innovation markets, the empirical results give a better understanding of the different roles patents play - roles that have not necessarily been covered by previous studies. Patents are by managers perceived to improve value capture in all markets in our conceptual framework. Patent rights seem to enable and improve product and service sales (Table 7), technology sales (Table 6) and sales of financial instruments (Tables 5 and 7).

Patents are also clearly and significantly positively correlated with secrecy, which in turn is positively correlated with keeping personnel as well as with production cost reductions. This makes sense since trade secrets typically are embodied in personnel, especially in startups, and many firms keep processes secret while patenting products. Thus, patents may play an indirect and apparently complementary role to other means for improving value capture, besides their direct role. For example, patents and secrets are (by design) important means for creating market lead times, but not the only means (Granstrand, 2018).

Given these complementarities across different means of capturing innovation value it is natural to ask about the nature and strength of these effects. One way of separating indirect effects upon importance is by counterfactual analysis, here based on counterfactual survey questions. Our results (see Table 3) show highly significant and fairly strong effects of patents. The positive values in the counterfactual answers imply that without patents the firms would have to rely more heavily on the remaining means for appropriation, especially on secrecy and market lead times.

Our results also indicate that patenting is enabling appropriation on a higher level. Without patents, firms would according to our results rely more heavily on producing and selling products and services to capture returns from their innovations. A surprising result in this context is that the perceived impact from patents upon R\&D investments in startups is insignificant (see Table 7), which runs counter to the standard theoretical rationale for patents as incentivizing private $R \& D$ investments for producing and selling new products and services - while it resonates with a common skepticism of patents among startup founders (Holgersson, 2013). However, patents not only enable appropriation in product and service markets, but also by selling, technologies, licenses, shares and by capturing value through debt financing. This is in line with more recent research showing that patents are
Value capture in open innovation markets

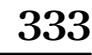


EJIM

25,6

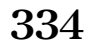

related to improved financing with venture capital (e.g. Mann and Sager, 2007; Munari and Oriani, 2011; Haeussler et al., 2014), and goes in line with the view of patents as a basis for contracting, allowing all kinds of deals and contractual relationships in various markets (Merges, 2011; Granstrand, 2020). The contractual nature of patents as means for value capture may - relative to other means - be especially well suited for external relationships and market exchange more prone to opportunism (Hagedoorn and Zobel, 2015; Holgersson et al.,2018). Patents reduce information asymmetries in markets for technologies as well as in markets for capital (Haeussler et al., 2014), and they protect buyers from expropriation risks in technology trade (De Rassenfosse et al., 2016) and financial risk in debt financing (Fischer and Ringler, 2014; De Rassenfosse and Fischer, 2016).

The markets in our conceptual framework, including product and service markets, markets for collaboration, technology markets, and markets for financing and corporate control, can then be used more effectively. Global technology markets have grown considerably since the pro-patent era emerged in the 1980s (Arora et al., 2001). At about the same time global financial markets have proliferated. The supply and demand conditions in these markets are naturally important for open innovation and financing. Patent rights are essential to the functioning of technology markets and apparently to markets for collaboration, financing and corporate control as well, just as property rights are essential to any type of market (Arrow, 1962; North, 1990).

\section{Conclusions and implications}

In this paper we have conceptualized open innovation markets and investigated the importance of patents for appropriation in such markets. Since some form of trade or exchange is necessary for a firm to capture value from innovation we drew from research on open innovation and developed and used a framework of distinct types of markets on which appropriation takes place (see Figure 2). Our results indicate that patents widen the range of useful markets for appropriation. Without patents firms would focus more narrowly on inhouse development, production and sales of technology-based products and services at the expense of sales of technologies and sales of equity, bonds and other financial instruments. In other words, patents enable and induce the use of technology markets as well as financial markets for appropriation. The results moreover show that the importance of patents has a skewed distribution with many firms rating patents as very important but with a fat tail of firms rating patents less important. At the same time patents are complementary to other means of appropriation usually rated higher in importance, such as creating market lead times, and these indirect complementary effects are typically not accounted for. This partly explains the limited importance of patents that previous studies have communicated. Nevertheless, patents are by respondents perceived to function in the traditional ways as expected-boosting sales and sales margins in product and service markets-although relatively weakly. The impact of patenting is perceived to be stronger regarding boosting enterprise value and enabling use of financial markets, especially equity sales.

Our conceptualization of appropriation in different types of markets is important for understanding the wide range of roles patent rights (and other means) can play for capturing innovation value and our empirical results show that new roles might eventually be more important than traditional ones as technology markets and new financial markets develop. This calls for continued research on the various roles patent rights and other types of IPRs can play for different ways of capturing - and creating - value from innovation. Moreover, managers need not only to consider if and how a patent can promote an in-house commercialization strategy, but maybe even more importantly if and how a patent can be used to enable appropriation in a broader sense. In so doing, the impact upon value capture and competitiveness from a wider range of complementary strategies can be strengthened, 
which might be especially valuable for technology based startups who are still in search for complementary assets (Teece, 1986) and viable business models (Chesbrough and Rosenbloom, 2002). Thus, while previous research has indicated that especially small firms struggle with benefitting from patenting in the traditional way by protecting sales in product and service markets, this study indicates that startups as well as larger firms nevertheless have much to lose in other markets by not patenting at all.

\section{Notes}

1. The receipt of donations, grants and subsidies from sponsors without contractual obligations may be included in the fourth market category or added as a fifth category of markets. We do not focus on it specifically here, however.

2. Two of the responses were identified as irrelevant for much of the analysis due to their limited technology development.

3. A patent examiner in assessing whether the invention in a patent application fulfills an inventive step requirement has to assess whether the invention at the date of application was obvious or not for a person skilled in the art. Thus the examiner has to perform an a priori thought experiment backcast in time and role cast as a person skilled in the art under the counterfactual assumption of having no posterior knowledge past that date. Overly complex as it seems, the counterfactual analysis is after all performed daily in various patent offices around the world, as well as in court proceedings that very well may follow upon such uncontrollable experiments.

4. This is the same type of value function as in a cooperative game. $S \backslash j$ is shorthand notation for $S \backslash\{j\}$ and $[n]:=\{1,2, \ldots, n\}$.

5. This type of rationalization of behavior does not remove all apparent contradictions in observed patenting behaviors, however. For example, firms do maintain many patents for their full term (normally 20 years), some of which are never commercialized. There might be reasons for this behavior as well but then of another nature (e.g. routines and bounded rationality). Neither nonoptimal behavior nor trade-offs are necessarily involving paradoxical contradictions.

\section{References}

Adner, R. (2006), "Match your innovation strategy to your innovation ecosystem", Harvard Business Review, Vol. 84, pp. 98-107.

Agostini, L. and Nosella, A. (2019), "Inter-organizational relationships involving SMEs: a bibliographic investigation into the state of the art", Long Range Planning, Vol. 52, pp. 1-31.

Agostini, L., Caviggioli, F., Filippini, R. and Nosella, A. (2015), "Does patenting influence SME sales performance? A quantity and quality analysis of patents in Northern Italy", European Journal of Innovation Management, Vol. 18, pp. 238-257.

Alexy, O., Criscuolo, P. and Salter, A. (2009), “Does IP strategy have to cripple open innovation?”, MIT Sloan Management Review, Vol. 51, pp. 71-77.

Arora, A., Fosfuri, A. and Gambardella, A. (2001), Markets for Technology: The Economics of Innovation and Corporate Strategy, MIT Press, Cambridge, MA.

Arora, A., Fosfuri, A. and Rønde, T. (2013), "Managing licensing in a market for technology", Management Science, Vol. 59, pp. 1092-1106.

Arora, A., Fosfuri, A. and Rønde, T. (2021), "Waiting for the payday? The market for startups and the timing of entrepreneurial exit”, Management Science, Vol. 67, pp. 1453-1467.

Arrow, K.J. (1962), "Economic welfare and the allocation of resources for invention", in National Bureau of Economic Research (Ed.), The Rate and Direction of Inventive Activity: Economic and Social Factors, Princeton University Press, Princeton, NJ.

Arundel, A. (2001), "The relative effectiveness of patents and secrecy for appropriation", Research Policy, Vol. 30, pp. 611-624.
Value capture in open innovation markets 
EJIM

25,6

Arundel, A. and Kabla, I. (1998), "What percentage of innovations are patented? Empirical estimates for European firms", Research Policy, Vol. 27, pp. 127-141.

Bader, M.A. (2006), Intellectual Property Management in R\&D Collaborations: The Case of the Service Industry Sector, Physica-Verlag, Heidelberg.

Bigliardi, B., Ferraro, G., Filippelli, S. and Galati, F. (2020), "The past, present and future of open innovation”, European Journal of Innovation Management, Vol. 24 No. 4, pp. 1130-1161, doi: 10. 1108/EJIM-10-2019-0296.

Björkdahl, J. (2009), "Technology cross-fertilization and the business model: the case of integrating ICTs in mechanical engineering products", Research Policy, Vol. 38, pp. 1468-1477.

Bloom, N. and Van Reenen, J. (2002), "Patents, real options and firm performance", The Economic Journal, Vol. 112, pp. C97-C116.

Bogers, M. (2011), "The open innovation paradox: knowledge sharing and protection in R\&D collaborations", European Journal of Innovation Management, Vol. 14, pp. 93-117.

Brouwer, E. and Kleinknecht, A. (1999), "Innovative output, and a firm's propensity to patent.: an exploration of CIS micro data", Research Policy, Vol. 28, pp. 615-624.

Bucherer, E., Eisert, U. and Gassmann, O. (2012), "Towards systematic business model innovation: lessons from product innovation management", Creativity and Innovation Management, Vol. 21, pp. 183-198.

Burgelman, R.A., Floyd, S.W., Laamanen, T., Mantere, S., Vaara, E. and Whittington, R. (2018), "Strategy processes and practices: dialogues and intersections", Strategic Management Journal, Vol. 39, pp. 531-558.

Cassiman, B. and Veugelers, R. (2006), "In search of complementarity in innovation strategy: internal R\&D and external knowledge acquisition”, Management Science, Vol. 52, pp. 68-82.

Chesbrough, H.W. (2003), Open Innovation: The New Imperative for Creating and Profiting from Technology, Harvard Business School Press, Boston, MA.

Chesbrough, H.W. and Chen, E.L. (2013), "Recovering abandoned compounds through expanded external IP licensing”, California Management Review, Vol. 55, pp. 83-101.

Chesbrough, H.W. and Rosenbloom, R.S. (2002), "The role of the business model in capturing value from innovation: evidence from Xerox Corporation's technology spin-off companies”, Industrial and Corporate Change, Vol. 11, pp. 529-555.

Chirico, F., Criaco, G., Baù, M., Naldi, L., Gomez-Mejia, L.R. and Kotlar, J. (2020), "To patent or not to patent: that is the question. Intellectual property protection in family firms", Entrepreneurship Theory and Practice, Vol. 44, pp. 339-367.

Coase, R.H. (1937), “The nature of the firm”, Economica, Vol. 4, pp. 386-405.

Cohen, W.M., Nelson, R.R. and Walsh, J.P. (2000), "Protecting their intellectual assets: appropriability conditions and why US manufacturing firms patent (Or Not)", Working Paper 7552, National Bureau of Economic Research (NBER), available at: http://www.nber.org/papers/w7552.

Conti, A., Thursby, J. and Thursby, M. (2013), "Patents as signals for startup financing”, The Journal of Industrial Economics, Vol. 61, pp. 592-622.

Dahlander, L. and Gann, D.M. (2010), "How open is innovation?", Research Policy, Vol. 39, pp. 699-709.

Dahlander, L. and Wallin, M.W. (2006), "A man on the inside: unlocking communities as complementary assets”, Research Policy, Vol. 35, pp. 1243-1259.

Dahlander, L., Gann, D.M. and Wallin, M.W. (2021), "How open is innovation? A retrospective and ideas forward”, Research Policy, Vol. 50, p. 104218.

De Rassenfosse, G. and Fischer, T. (2016), "Venture debt financing: determinants of the lending decision”, Strategic Entrepreneurship Journal, Vol. 10, pp. 235-256.

De Rassenfosse, G., Palangkaraya, A. and Webster, E. (2016), "Why do patents facilitate trade in technology? Testing the disclosure and appropriation effects”, Research Policy, Vol. 45, pp. 1326-1336. 
Elmquist, M., Fredberg, T. and Ollila, S. (2009), "Exploring the field of open innovation", European Journal of Innovation Management, Vol. 12, pp. 326-345.

Enkel, E., Gassmann, O. and Chesbrough, H.W. (2009), "Open R\&D and open innovation: exploring the phenomenon”, R\&D Management, Vol. 39, pp. 311-316.

Fischer, T. and Ringler, P. (2014), "What patents are used as collateral?-an empirical analysis of patent reassignment data", Journal of Business Venturing, Vol. 29, pp. 633-650.

Freeman, R.E. (2015), "Stakeholder theory", in Wiley Encyclopedia of Management.

Gans, J. and Ryall, M.D. (2017), "Value capture theory: a strategic management review", Strategic Management Journal, Vol. 38, pp. 17-41.

Granstrand, O. (1982), Technology, Management and Markets: An Investigation of R\&D and Innovation in Industrial Organizations, Frances Pinter, London.

Granstrand, O. (1998), "Towards a theory of the technology-based firm”, Research Policy, Vol. 27, pp. $465-489$.

Granstrand, O. (1999), The Economics and Management of Intellectual Property: Towards Intellectual Capitalism, Edward Elgar Publishing, Cheltenham.

Granstrand, O. (2000), "The shift towards intellectual capitalism: the role of infocom technologies", Research Policy, Vol. 29, pp. 1061-1080.

Granstrand, O. (2018), Evolving Properties of Intellectual Capitalism: Patents and Innovations for Growth and Welfare, Edward Elgar Publishing, Cheltenham.

Granstrand, O. (2020), "Towards a theory of innovation governance and the role of IPRs", GRUR International, Vol. 69, pp. 341-354.

Granstrand, O. and Holgersson, M. (2013), "Managing the intellectual property disassembly problem”, California Management Review, Vol. 55, pp. 184-210.

Granstrand, O. and Holgersson, M. (2020), "Innovation ecosystems: a conceptual review and a new definition”, Technovation, Vols 90-91, pp. 1-12.

Granstrand, O. and Sjölander, S. (1990), "The acquisition of technology and small firms by large firms", Journal of Economic Behavior and Organization, Vol. 13, pp. 367-386.

Granstrand, O., Bohlin, E., Oskarsson, C. and Sjöberg, N. (1992), "External technology acquisition in large multi-technology corporations", R\&D Management, Vol. 22, pp. 111-133.

Haeussler, C., Harhoff, D. and Mueller, E. (2014), "How patenting informs VC investors - the case of biotechnology", Research Policy, Vol. 43, pp. 1286-1298.

Hagedoorn, J. and Zobel, A.-K. (2015), "The role of contracts and intellectual property rights in open innovation”, Technology Analysis and Strategic Management, Vol. 27, pp. 1050-1067.

Hall, B.H. and Ziedonis, R.H. (2001), "The patent paradox revisited: an empirical study of patenting in the U.S. semiconductor industry, 1979-1995", The RAND Journal of Economics, Vol. 32, pp. 101-128.

Harabi, N. (1995), “Appropriability of technical innovations an empirical analysis”, Research Policy, Vol. 24, pp. 981-992.

Harhoff, D., Scherer, F.M. and Vopel, K. (2003), "Exploring the tail of patented invention value distributions", in Granstrand, O. (Ed.), Economics, Law and Intellectual Property, Kluwer Academic Publishers, Dordrecht.

Heeley, M.B., Matusik, S.F. and Jain, N. (2007), "Innovation, appropriability, and the underpricing of initial public offerings", Academy of Management Journal, Vol. 50, pp. 209-225.

Hochberg, Y.V., Serrano, C.J. and Ziedonis, R.H. (2018), "Patent collateral, investor commitment, and the market for venture lending", Journal of Financial Economics, Vol. 130, pp. 74-94.

Holgersson, M. (2013), "Patent management in entrepreneurial SMEs: a literature review and an empirical study of innovation appropriation, patent propensity, and motives", $R \& D$ Management, Vol. 43, pp. 21-36. 
EJIM

25,6
Holgersson, M. and Granstrand, O. (2017), "Patenting motives, technology strategies, and open innovation”, Management Decision.

Holgersson, M., Granstrand, O. and Bogers, M. (2018), "The evolution of intellectual property strategy in innovation ecosystems: uncovering complementary and substitute appropriability regimes", Long Range Planning, Vol. 51, pp. 303-319.

Jeppesen, L.B. and Lakhani, K.M. (2010), "Marginality and problem solving effectiveness in broadcast search”, Organization Science, Vol. 21, pp. 1016-1033.

Kato, M., Onishi, K. and Honjo, Y. (2021), "Does patenting always help new firm survival? Understanding heterogeneity among exit routes", Small Business Economics.

Kim, C.-J., Morley, J. and Piger, J. (2008), "Bayesian counterfactual analysis of the sources of the great moderation", Journal of Applied Econometrics, Vol. 23, pp. 173-191.

Kitching, J. and Blackburn, R. (1998), "Intellectual property management in the small and medium enterprise (SME)”, Journal of Small Business and Enterprise Development, Vol. 5, pp. 327-335.

Laursen, K. and Salter, A. (2006), "Open for innovation: the role of openness in explaining innovation performance among U.K. manufacturing firms", Strategic Management Journal, Vol. 27, pp. 131-150.

Laursen, K., Moreira, S., Reichstein, T. and Leone, M.I. (2017), "Evading the boomerang effect: using the grant-back clause to further generative appropriability from technology licensing deals", Organization Science, Vol. 28, pp. 514-530.

Leiponen, A. and Byma, J. (2009), "If you cannot block, you better run: small firms, cooperative innovation, and appropriation strategies”, Research Policy, Vol. 38, pp. 1478-1488.

Levin, R.C., Klevorick, A.K., Nelson, R.R. and Winter, S.G. (1987), "Appropriating the returns from industrial research and development", Brookings Papers on Economic Activity, Vol. 14, pp. 783-831.

Lopez-Vega, H., Tell, F. and Vanhaverbeke, W. (2016), "Where and how to search? Search paths in open innovation”, Research Policy, Vol. 45, pp. 125-136.

Mann, R.J. and Sager, T.W. (2007), "Patents, venture capital, and software start-ups", Research Policy, Vol. 36, pp. 193-208.

Mansfield, E. (1986), "Patents and innovation: an empirical study", Management Science, Vol. 32, pp. 173-181.

Mansfield, E. (1988), "The speed and cost of industrial innovation in Japan and the United States: external vs. Internal technology", Management Science, Vol. 34, pp. 1157-1168.

Merges, R.P. (2011), Justifying Intellectual Property, Harvard University Press, Cambridge, MA.

Munari, F. and Oriani, R. (2011), The Economic Valuation of Patents: Methods and Applications, Edward Elgar Publishing, Cheltenham.

North, D.C. (1981), Structure and Change in Economic History, Norton, New York, NY.

North, D.C. (1990), Institutions, Institutional Change, and Economic Performance, Cambridge University Press, Cambridge.

Nylund, P.A., Arimany-Serrat, N., Ferras-Hernandez, X., Viardot, E., Boateng, H. and Brem, A. (2019), "Internal and external financing of innovation: sectoral differences in a longitudinal study of European firms", European Journal of Innovation Management, Vol. 23, pp. 200-213.

Osterwalder, A. and Pigneur, Y. (2010), Business Model Generation: A Handbook for Visionaries, Game Changers, and Challengers, John Wiley \& Sons, Hoboken, New Jersey.

Schwartz, E.S. (2004), "Patents and R\&D as real options", Economic Notes, Vol. 33, pp. 23-54.

Shaikh, M. and Levina, N. (2019), "Selecting an open innovation community as an alliance partner: looking for healthy communities and ecosystems", Research Policy, Vol. 48, p. 103766.

Spender, J.-C., Corvello, V., Grimaldi, M. and Rippa, P. (2017), "Startups and open innovation: a review of the literature", European Journal of Innovation Management, Vol. 20, pp. 4-30. 
Stoelhorst, J.W. (Forthcoming), "Value, rent, and profit: a stakeholder resource-based theory", Strategic Management Journal.

Teece, D.J. (1986), "Profiting from technological innovation: implications for integration, collaboration, licensing and public policy", Research Policy, Vol. 15, pp. 285-305.

Teece, D.J. (2010), "Business models, business strategy and innovation”, Long Range Planning, Vol. 43, pp. 172-194.

Tietze, F. (2012), Technology Market Transactions, Edward Elgar Publishing, Cheltenham.

Usman, M. and Vanhaverbeke, W. (2017), "How start-ups successfully organize and manage open innovation with large companies", European Journal of Innovation Management, Vol. 20, pp. 171-186.

Van De Vrande, V., De Jong, J.P.J., Vanhaverbeke, W. and De Rochemont, M. (2009a), "Open innovation in SMEs: trends, motives and management challenges", Technovation, Vol. 29, pp. $423-437$.

Van De Vrande, V., Vanhaverbeke, W. and Duysters, G. (2009b), "External technology sourcing: the effect of uncertainty on governance mode choice", Journal of Business Venturing, Vol. 24, pp. $62-80$.

Vanhaverbeke, W., Duysters, G. and Noorderhaven, N. (2002), "External technology sourcing through alliances or acquisitions: an analysis of the application-specific integrated circuits industry", Organization Science, Vol. 13, pp. 714-733.

Vanhaverbeke, W., Van De Vrande, V. and Chesbrough, H.W. (2008), "Understanding the advantages of open innovation practices in corporate venturing in terms of real options", Creativity and Innovation Management, Vol. 17, pp. 251-258.

West, J. and Bogers, M. (2014), "Leveraging external sources of innovation: a review of research on open innovation", Journal of Product Innovation Management, Vol. 31, pp. 814-831.

Williamson, O.E. (1975), Markets and Hierarchies: Analysis and Antitrust Implications, Free Press, New York, NY.

Zobel, A.-K. and Hagedoorn, J. (2020), "Implications of open innovation for organizational boundaries and the governance of contractual relations", Academy of Management Perspectives, Vol. 34, pp. 400-423.

Zobel, A.-K., Balsmeier, B. and Chesbrough, H. (2016), "Does patenting help or hinder open innovation? Evidence from new entrants in the solar industry", Industrial and Corporate Change, Vol. 25, pp. 307-331.

\section{Corresponding author}

Marcus Holgersson can be contacted at: marhol@chalmers.se

\section{Value capture in open innovation markets}

